\title{
Fabrication and microstructure of lithium nickel vanadium oxide prepared by solid-state reaction
}

\author{
Chung-Hsin Lu*, Shaw-Jang Liou \\ Department of Chemical Engineering, National Taiwan University, Taipei, Taiwan \\ Received 5 February 1998; accepted 1 July 1998
}

\begin{abstract}
The synthesis process and microstructural evolution of $\mathrm{LiNiVO}_{4}$, a potential cathode material used in lithium ion secondary batteries, prepared by solid-state reaction have been investigated in this study. The formation processes of $\mathrm{LiNiVO}_{4}$ are characterized to be an initial dissociation of $\mathrm{LiVO}_{3} \cdot 0.5 \mathrm{H}_{2} \mathrm{O}$ to form $\mathrm{LiVO}_{3}$, followed by a subsequent reaction between $\mathrm{LiVO} 3$ and $\mathrm{NiO}$ to produce $\mathrm{LiNiVO}_{4}$ from above $600^{\circ} \mathrm{C}$. After calcination at $700^{\circ} \mathrm{C}$ for $6 \mathrm{~h}$, monophasic $\mathrm{LiNiVO}_{4}$ has been successfully prepared. Further raising the temperature to $800^{\circ} \mathrm{C}$ reduces the required heating time to $4 \mathrm{~h}$. In comparison with the results in previous reports, the heating time for synthesizing $\mathrm{LiNiVO}_{4}$ is significantly reduced in the study. The microstructure of $\mathrm{LiNiVO}_{4}$ is found to markedly depend on the heating processes. Increasing heating temperature as well as soaking time results in non-uniform microstructure of the specimens. In the regions having nonstoichiometric composition, the microstructure of the specimens becomes well densified and experiences exaggerated grain-growth. The above phenomena imply that liquid-phase sintering has occurred in the above regions. (C) 1999 Elsevier Science Limited and Techna S.r.l. All rights reserved.
\end{abstract}

\section{Introduction}

Lithium ion batteries have been attracting considerable interest worldwide in the past few years in the field of rechargeable batteries because they posses high energy density, long cycle life, good safety, steady discharging properties, and wide range of working temperatures [1-3]. Currently, possible candidates for cathode for materials used in lithium ion batteries are mainly based on the systems of $\mathrm{LiCoO}_{2}, \mathrm{LiNiO}_{2}$, and $\mathrm{LiMn}_{2} \mathrm{O}_{4}$ [3]. Besides the above materials, recently lithium nickel vanadium oxide- $\mathrm{LiNiVO}_{4}$ has been found to be an alternative potential cathode material which affords a rather high voltage (up to $4.8 \mathrm{~V}$ ) in lithium cells $[4,5]$. Using $\mathrm{LiNiVO}_{4}$ in cathodes can offer great promises of increasing the energy density of batteries. In addition, $\mathrm{LiNiVO}_{4}$ exhibits an unusual inverse spinel structure which is different from the crystal structures of other lithium-incorporated cathode materials. The high voltage capability of $\mathrm{LiNiVO}_{4}$ might be related to its crystal structure.

\footnotetext{
* Corresponding author. Tel.: + 886-2-365-1428; fax: +886-2-362-
}

Several researchers have used different types of raw materials for preparing $\mathrm{LiNiVO}_{4}$. Bernier et al. adopted $\mathrm{LiVO}_{3}$ and $\mathrm{NiCO}_{3}$ as raw materials, and found that heating the mixtures at $500^{\circ} \mathrm{C}$ for 7 days was required for obtaining $\mathrm{LiNiVO}_{4}$ [6]. Ito used $\mathrm{NiO}$ rather than $\mathrm{NiCO}_{3}$ in the above reaction, and increased the heating temperature up to $1000^{\circ} \mathrm{C}$ [7]. However, this heating process had to progress for as long as 4 days for producing $\mathrm{LiNiVO}_{4}$. Fey synthesized $\mathrm{LiNiVO}_{4}$ by reacting $\mathrm{LiNiO}_{2}$ with $\mathrm{V}_{2} \mathrm{O}_{5}$ [8], and effectively reduced the required heating temperature. Nevertheless, heating the mixtures for $24 \mathrm{~h}$ at $650^{\circ} \mathrm{C}$ is still necessary.

Although $\mathrm{LiNiVO}_{4}$ has been successfully synthesized in the above studies, and its electrochemical properties have been explored, the formation mechanism and microstructural evolution of $\mathrm{LiNiVO}_{4}$ have not yet been thoroughly investigated. The details related to reaction process are crucial for controlling calcination conditions, as well as to obtain the monophasic compound that has uniform microstructure and fine grains, which significantly influence the packing density of cathodes and electrochemical properties of batteries. Therefore, the aim of this work is to first elucidate the formation process of $\mathrm{LiNiVO}_{4}$ in solid-state reaction. Secondly, the optimal processing conditions are determined for 
synthesizing the pure compound. Furthermore, the influence of heating conditions on microstructure and grain size of the obtained $\mathrm{LiNiVO}_{4}$ are also examined.

\section{Experimental}

Proportionate amounts of reagent-grade starting materials $\mathrm{Li}_{2} \mathrm{CO}_{3}, \mathrm{NiO}$, and $\mathrm{V}_{2} \mathrm{O}_{5}$ were mixed according to the composition of $\mathrm{LiNiVO}_{4}$, followed by ball-milling for $48 \mathrm{~h}$ with ethyl alcohol, using zirconia balls in a polyethylene jar. After drying in a rotary evaporator under reduced pressure, the starting materials of $\mathrm{LiNiVO}_{4}$ were obtained. Because the dried powder absorbed moisture easily, the powder was stored in a dry box. The endothermic/exothermic reactions and weight change of specimens of the mixed powder were examined by differential thermal analysis (DTA) and thermogravimetry analysis (TGA). After the mixed powder was uniaxially pressed into disks under 196 $\mathrm{MPa}$, the pressed disks were heated in a furnace at temperature ranging from $400-1000^{\circ} \mathrm{C}$. When reaching the pre-set temperature, the pressed pellets were quickly removed from the furnace and then rapidly cooled in air to investigate the phases formed in reactions. The compounds present in specimens were identified via X-ray powder diffraction (XRD) analysis using $\mathrm{CuK}_{\alpha}$ radiation. For producing pure $\mathrm{LiNiVO}_{4}$ compound, calcination at different temperatures was also performed. Microstructural evolution in the quenched and soaked specimens was observed using a scanning electron microscope (SEM) coupled with energy dispersive X-ray spectroscopy (EDS).

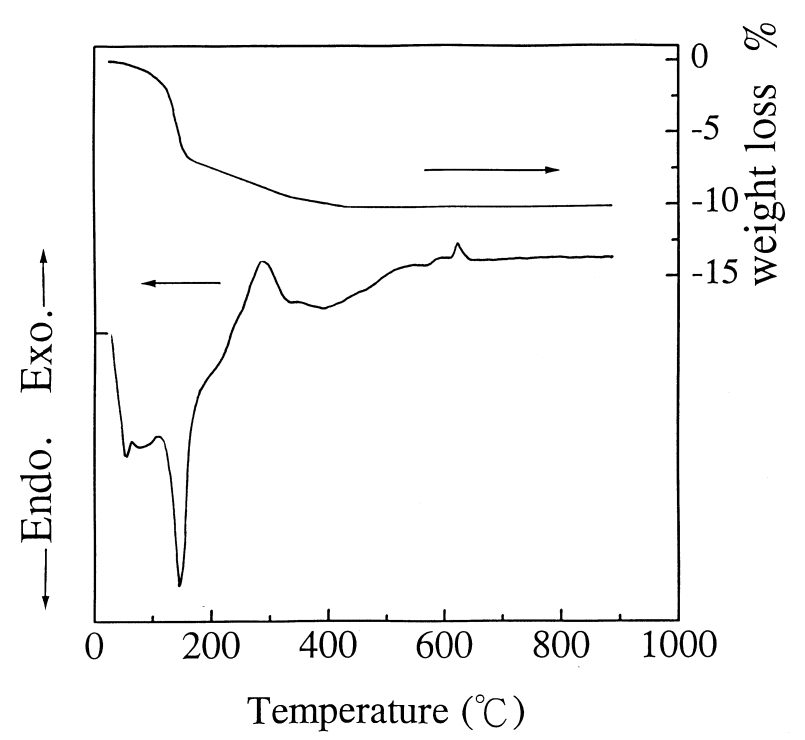

Fig. 1. (a) Differential thermal analysis and (b) thermogravimetric analysis of the starting materials of $\mathrm{LiNiVO}_{4}$.

\section{Results and discussion}

\subsection{Formation process of $\mathrm{LiNiVO}_{4}$}

Fig. 1 shows the DTA and TGA results of the starting materials of $\mathrm{LiNiVO}_{4}$ from room temperature to $900^{\circ} \mathrm{C}$. A broad endothermic peak appears from around $50^{\circ} \mathrm{C}$, which is due to the desoprtion of water. A sharp endothermic peak occurs at around $150^{\circ} \mathrm{C}$, accompanied by a large weight loss of $6 \%$. Following that, a large exothermic peak is formed at around $300^{\circ} \mathrm{C}$, and several small peaks appear at around $600^{\circ} \mathrm{C}$. At temperature higher than $400^{\circ} \mathrm{C}$, no further weight loss is observed.

For analyzing the formation mechanism of $\mathrm{LiNiVO}_{4}$, the starting materials were heated in a furnace and quenched at expected temperatures. The representative XRD patterns for the quenched specimens are shown in Fig. 2; in addition, the variation of resultant phases versus quenching temperatures is illustrated in Fig. 3. As indicated in Fig. 2 (a), before heat-treatment, a small amount of $\mathrm{LiVO}_{3} \cdot 0.5 \mathrm{H}_{2} \mathrm{O}$ is present with $\mathrm{NiO}$ in the mixed starting-materials. The formation of $\mathrm{LiVO}_{3}$ $0.5 \mathrm{H}_{2} \mathrm{O}$ is believed to result from the mechanochemical reaction between $\mathrm{Li}_{2} \mathrm{CO}_{3}$ and $\mathrm{V}_{2} \mathrm{O}_{5}$ during the ball-milling process. Similar phenomenon was also found in the preparation of the starting materials of $\mathrm{Pb}\left(\mathrm{Li}_{1 / 4} \mathrm{Fe}_{1 / 4} \mathrm{~W}_{1 / 2}\right) \mathrm{O}_{3}$ [9]. After heating at $500^{\circ} \mathrm{C}$, all $\mathrm{LiVO}_{3} \cdot 0.5 \mathrm{H}_{2} \mathrm{O}$ has converted into $\mathrm{LiVO}_{3}$. Therefore, the sharp endotherm at $150^{\circ} \mathrm{C}$ on DTA and the large weight

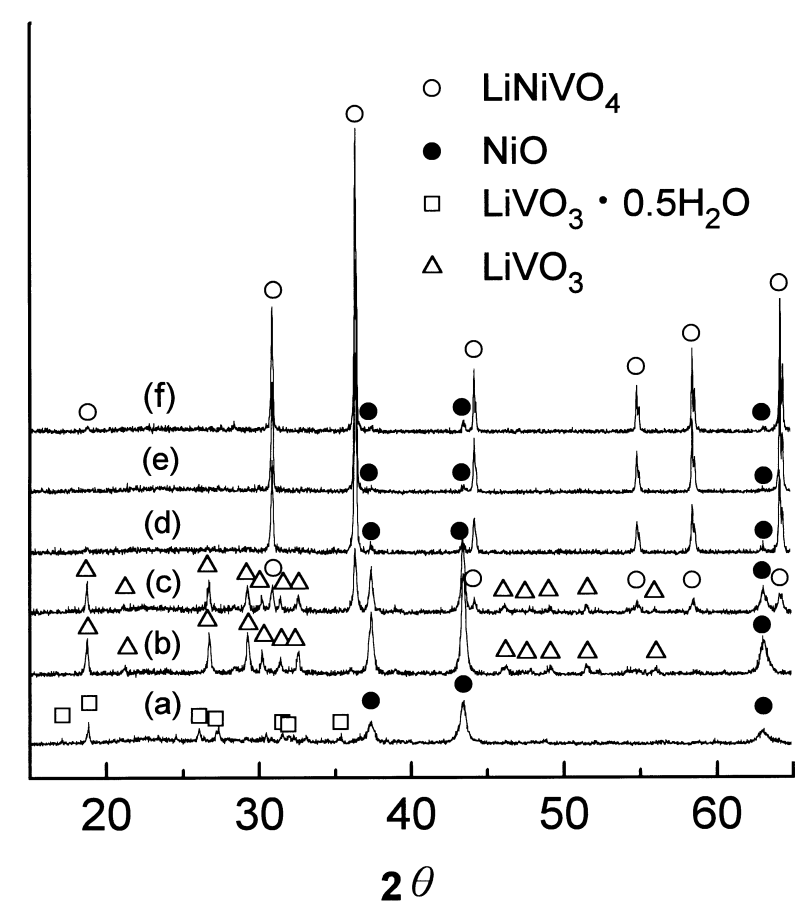

Fig. 2. X-ray diffraction patterns of (a) the as-prepared $\mathrm{LiNiVO}_{4}$ precursor and the precursor quenched at (b) $500^{\circ} \mathrm{C}$, (c) $600^{\circ} \mathrm{C}$, (d) $700^{\circ} \mathrm{C}$, and (e) $800^{\circ} \mathrm{C}$, and (f) $1000^{\circ} \mathrm{C}$. 


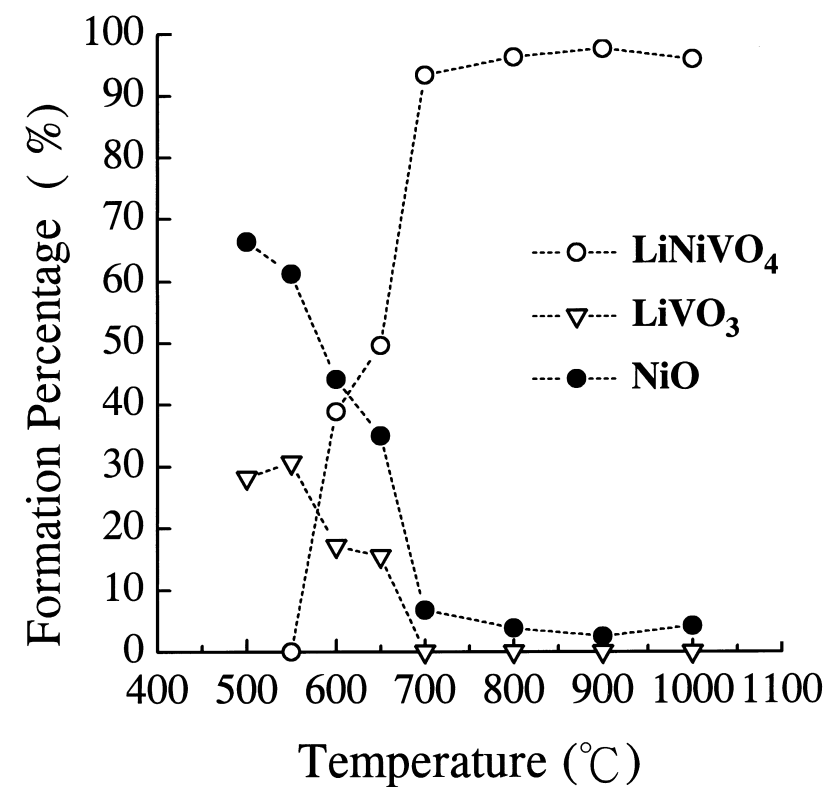

Fig. 3. Relative percentage of resulting compounds vs quenching temperatures for the staring materials of $\mathrm{LiNiVO}_{4}$

loss on TGA are attributed to the dissociation of water from $\mathrm{LiVO}_{3} \cdot 0.5 \mathrm{H}_{2} \mathrm{O}$. The exotherm at around $300^{\circ} \mathrm{C}$ is caused by the combustion of polyethylene contaminant during ball-milling, as observed in the previous study [10]. When heating temperature reaches $600^{\circ} \mathrm{C}$ [Fig. 2(c)], the phase of $\mathrm{LiNiVO}_{4}$ begins to form. Thus, the DTA peaks appearing at around $600^{\circ} \mathrm{C}$ are ascribed to the formation of $\mathrm{LiNiVO}_{4}$. As shown in Fig. 3, at temperatures above $700^{\circ} \mathrm{C}$, the amount of $\mathrm{LiNiVO}_{4}$ rapidly increases with the rise in heating temperature, and the amount of $\mathrm{LiVO}_{3}$ correspondingly decreases. At above $800^{\circ} \mathrm{C}$, the reaction of $\mathrm{LiNiVO}_{4}$ is nearly complete, and the crystal structure of $\mathrm{LiNiVO}_{4}$ is well developed. However, a trace of $\mathrm{NiO}$ is coexistent with $\mathrm{LiNiVO}_{4}$. Even at $1000^{\circ} \mathrm{C}$, the formation of $\mathrm{LiNiVO}_{4}$ is still not complete. Based on the above results, the formation mechanisms of $\mathrm{LiNiVO}_{4}$ can be expressed as the following equations:

$\mathrm{LiVO}_{3} \cdot 0.5 \mathrm{H}_{2} \mathrm{O} \stackrel{150^{\circ} \mathrm{C}}{\longrightarrow} \mathrm{LiVO}_{3}+0.5 \mathrm{H}_{2} \mathrm{O}$

$\mathrm{LiVO}_{3}+\mathrm{NiO} \stackrel{600^{\circ} \mathrm{C}}{\longrightarrow} \mathrm{LiNiVO}_{4}$

It is noted that no other intermediate compounds except for $\mathrm{LiVO}_{3}$ exist in the formation processes of $\mathrm{LiNiVO}_{4}$. The SEM photos of the specimens quenched at 600 and $700^{\circ} \mathrm{C}$ are shown in Fig. 4(a) and (b), respectively. At $600^{\circ} \mathrm{C}$, the specimen exhibits a porous feature. At $700^{\circ} \mathrm{C}$, the microstructure of the specimen becomes more densified, and the grain size of $\mathrm{LiNiVO}_{4}$ grows to $0.5-1.0 \mu \mathrm{m}$.

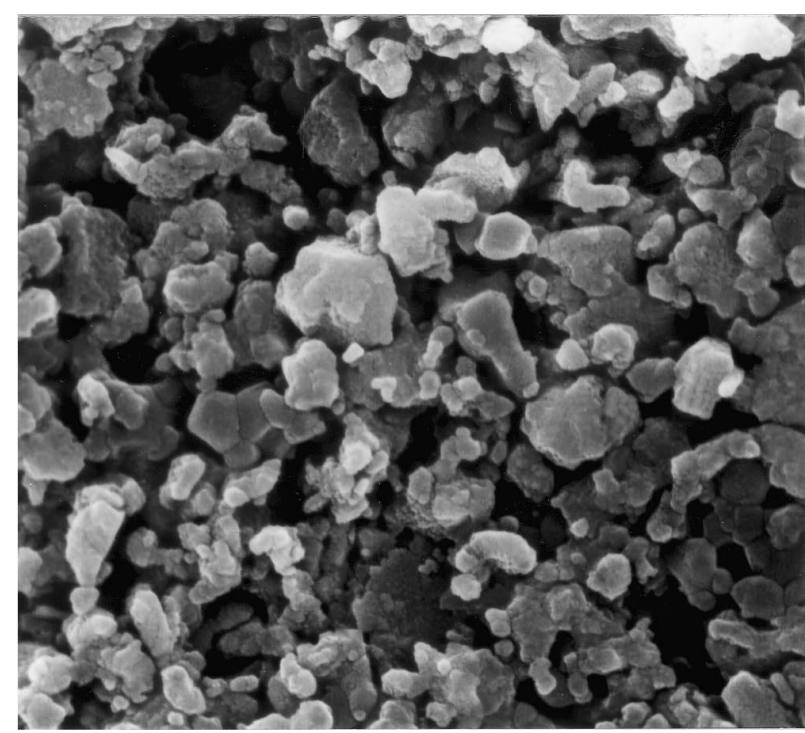

(a)

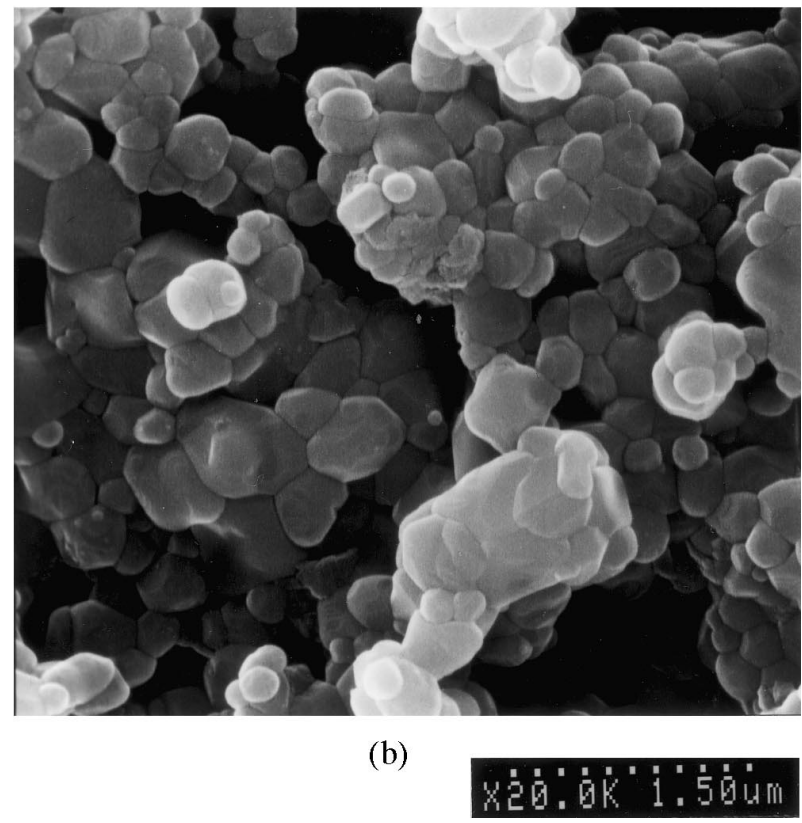

Fig. 4. Scanning electron micrographs of the starting materials of $\mathrm{LiNiVO}_{4}$ quenched at (a) $600^{\circ} \mathrm{C}$ and (b) $700^{\circ} \mathrm{C}$.

\subsection{Synthesis of monophasic $\mathrm{LiNiVO}_{4}$}

As described in Section 3.1, quenching the starting materials of $\mathrm{LiNiVO}_{4}$ at elevated temperatures results in the formation of $\mathrm{LiNiVO}_{4}$; however, this formation is incomplete, and a residual $\mathrm{NiO}$ phase coexists with $\mathrm{LiNiVO}_{4}$. For obtaining the pure phase of $\mathrm{LiNiVO}_{4}$, calcining the starting materials at different temperatures for various soaking time was conducted. With the increase in heating temperature and soaking time, the amount of $\mathrm{NiO}$ decreases. The XRD results of calcined specimens are summarized in Fig. 5. When 


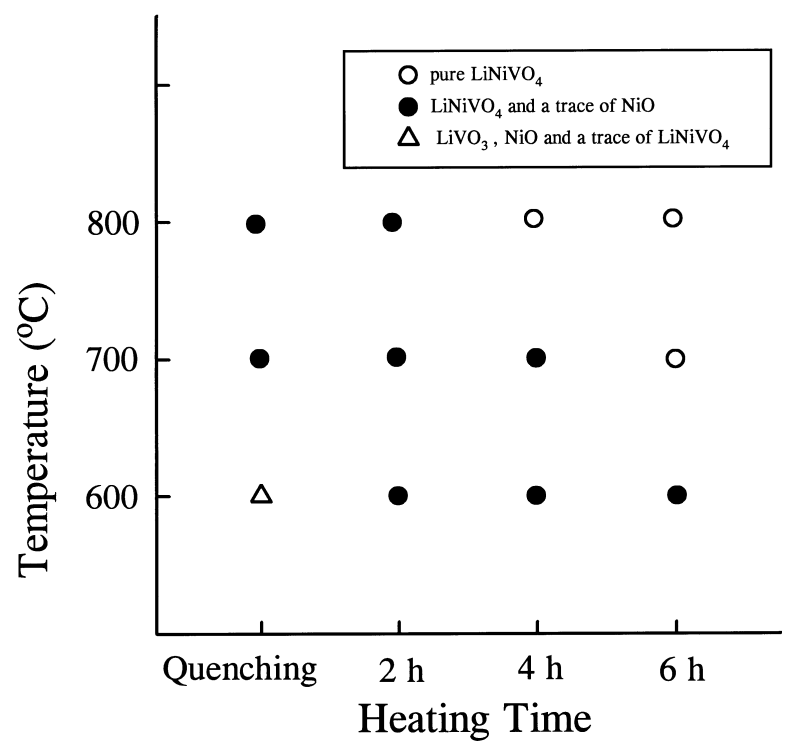

Fig. 5. Formation diagram of $\mathrm{LiNiVO}_{4}$ at various heating conditions.

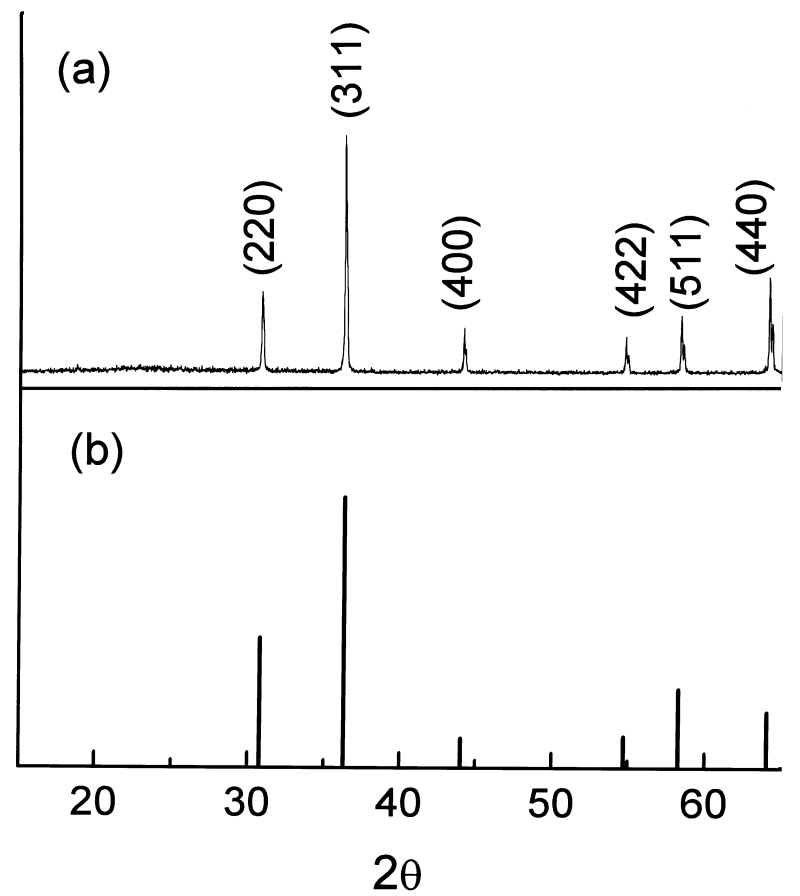

Fig. 6. X-ray diffraction pattern of $\mathrm{LiNiVO}_{4}$ (a) prepared at $700^{\circ} \mathrm{C}$ for $6 \mathrm{~h}$ and (b) reported in JCPDS file no. 38-1395 [11].

calcination at $600^{\circ} \mathrm{C}$ for $6 \mathrm{~h}$, a small amount of $\mathrm{NiO}$ is still present in the specimens. On the contrary, after calcination at $700^{\circ} \mathrm{C}$ for $6 \mathrm{~h}$, no $\mathrm{NiO}$ is detected, indicating that the formation of $\mathrm{LiNiVO}_{4}$ becomes complete. As the heating temperature reaches $800^{\circ} \mathrm{C}$, only 4-h soaking is needed to sufficiently result in monophasic $\mathrm{LiNiVO}_{4}$. Consequently, calcination for a prolonged period of time is found to be necessary for preparing pure $\mathrm{LiNiVO}_{4}$. In addition, the higher the calcination temperature, the less the soaking time is required. The XRD pattern of the obtained pure $\mathrm{LiNiVO}_{4}$ (heated at $700^{\circ} \mathrm{C}$ for $6 \mathrm{~h}$ ) is depicted in Fig. 6, and the hkl indexes are also presented in this figure. The d-spacing and intensity of each diffraction peak in the above XRD pattern are well consistent with those reported in JCPDS file no. 38-1395 [11], confirming that a pure $\mathrm{LiNiVO}_{4}$ compound has been synthesized. In comparison with the previously reported solid-state processes [6-8], it is found that in this study the required reaction time for preparing $\mathrm{LiNiVO}_{4}$ is significantly reduced. The high reactivity of the starting materials achieved in this study is probably ascribed to the better degree of mixing of the constituent species in the precursors.

\subsection{Microstructure of $\mathrm{LiNiVO}_{4}$}

The microstructures of the specimens calcined under various conditions are shown in Fig. 7. As shown in Fig. 7(a), after calcining at $700^{\circ} \mathrm{C}$ for $4 \mathrm{~h}$, the specimens exhibit uniform microstructure with grain size of 1.5-2.0 $\mu \mathrm{m}$. When the soaking time is prolonged to $6 \mathrm{~h}$, the microstructure of the specimens becomes non-uniform. In Fig. 7(b), some dark regions are found to distribute in the matrix. The area of dark regions markedly increases when the specimens are calcined at $800^{\circ} \mathrm{C}$ for $4 \mathrm{~h}$ [see Fig. 7 (c)]. As the $800^{\circ} \mathrm{C}$-calcination is prolonged to $6 \mathrm{~h}$, the dark regions cover most of the specimens [see Fig. 7 (d)].

The difference between the microstructure of the dark region and that of the matrix can be well distinguished on SEM photos with higher magnification. As shown in Fig. 8(a) for the $800^{\circ} \mathrm{C} / 6 \mathrm{~h}$ calcined-specimens, the dark region exhibits rather densified microstructure and experiences exaggerated grain-growth, implying that liquid-phase sintering has occurred in this region. In the same area, the $\mathrm{LiNiVO}_{4}$ grains exhibit flat morphology with size of around 10-20 $\mu \mathrm{m}$. On the other hand, in the matrix region, the $\mathrm{LiNiVO}_{4}$ grains become polyhedral, and their grain size falls between 3 and $5 \mu \mathrm{m}$ which is considerably smaller than that in the dark region. The compositions of the above two different regions were determined by EDS. Due to limitation of EDX equipment, lithium species could not be detected; whereas, the ratio of nickel/vanadium was determined. It was found that the ratio of nickel/vanadium in the matrix region is near unity, which is consistent with the stoichiometric amount of $\mathrm{LiNiVO}_{4}$; on the contrary, the ratio in the dark region is slightly lower than unity. It is confirmed that the composition of the specimens in certain regions deviates from stoichiometry, which would induce the formation of a liquid phase. The amount of the liquid phase is believed to increase with a rise in heating temperature as well as soaking time; therefore, the area of the dark region is correspondingly increased. Consequently, the above results reveal that 


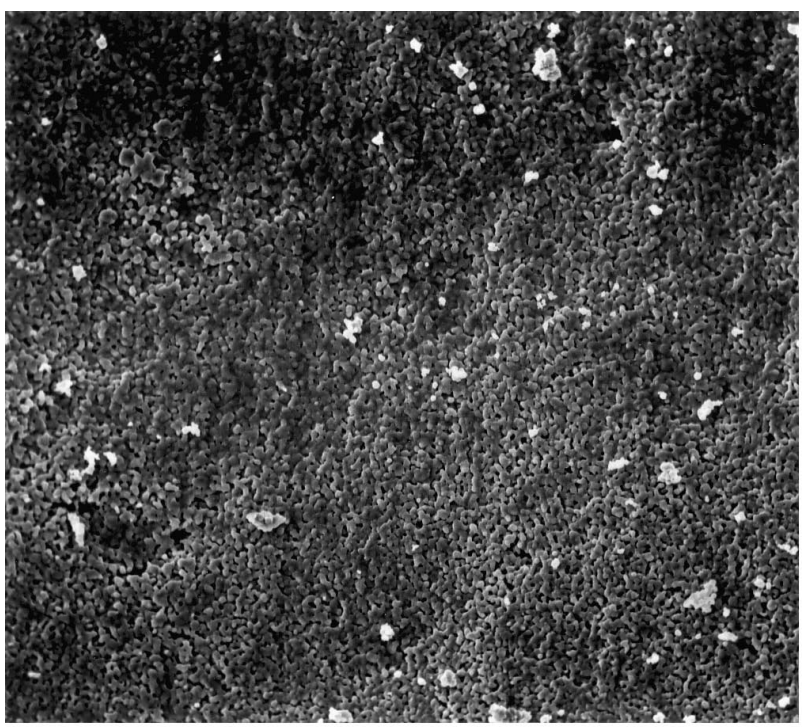

(a)

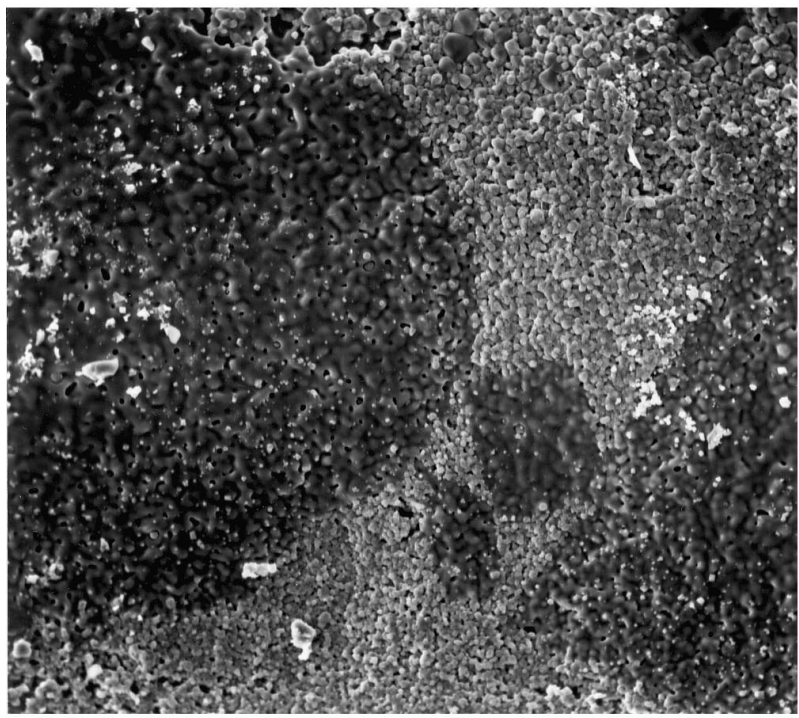

(c)

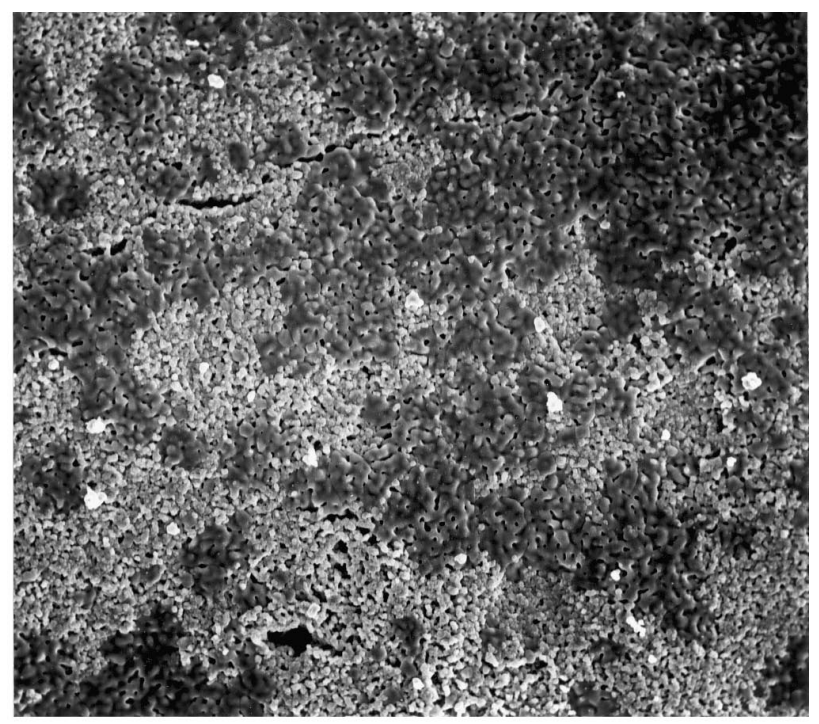

(b)

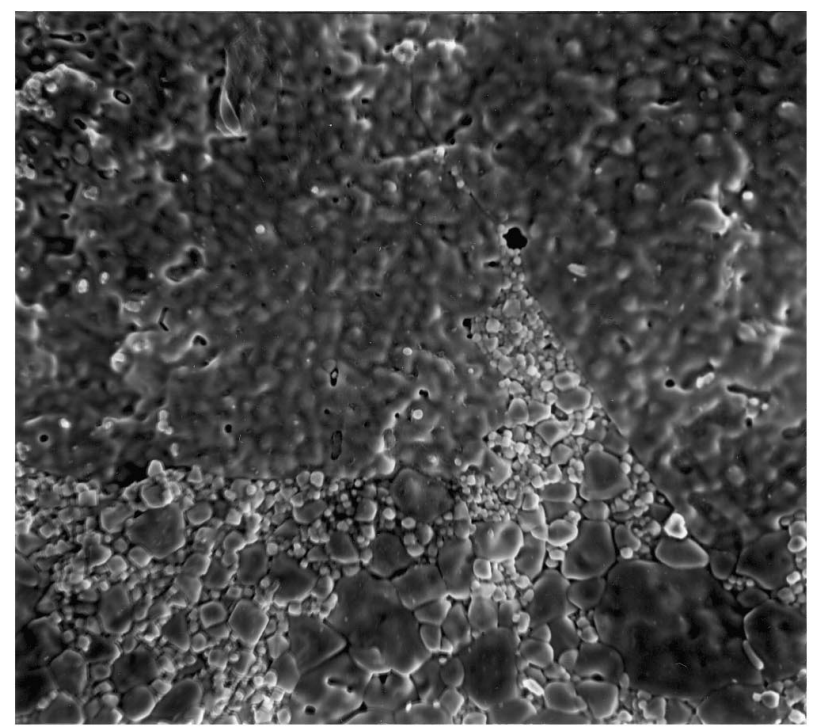

(d)

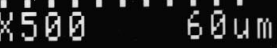

Fig. 7. Scanning electron micrographs of $\mathrm{LiNiVO}_{4}$ calcined at $700^{\circ} \mathrm{C}$ for (a) $4 \mathrm{~h}$ and (b) $6 \mathrm{~h}$, and $800^{\circ} \mathrm{C}$ for (c) $4 \mathrm{~h}$ and (d) $6 \mathrm{~h}$.

correct heating conditions and precise control of chemical composition are vitally required for obtaining monophasic $\mathrm{LiNiVO}_{4}$ having uniform microstructure and fine grain size.

\section{Conclusions}

The formation mechanism and microstructure of $\mathrm{LiNiVO}_{4}$ prepared by solid-state reaction have been studied. $\mathrm{LiVO}_{3} \cdot 0.5 \mathrm{H}_{2} \mathrm{O}$ is formed during the ball-milling process of the starting materials of $\mathrm{LiNiVO}_{4}$, and is subsequently dissociated to form $\mathrm{LiVO}_{3}$ at $150^{\circ} \mathrm{C}$. Then
$\mathrm{LiVO}_{3}$ reacts with $\mathrm{NiO}$ to generate $\mathrm{LiNiVO}_{4}$ at temperature higher than $600^{\circ} \mathrm{C}$. Quenching the starting materials of $\mathrm{LiNiVO}_{4}$ at elevated temperatures can yield a substantial amount of $\mathrm{LiNiVO}_{4}$; however, its formation is incomplete because of the coexistence of $\mathrm{NiO}$. On the other hand, calcination at $700^{\circ} \mathrm{C}$ for $6 \mathrm{~h}$ successfully results in monophasic $\mathrm{LiNiVO}_{4}$. In addition, increasing the calcination temperature to $800^{\circ} \mathrm{C}$ diminishes the required time to $4 \mathrm{~h}$. Compared with previous reports, this study significantly reduces the reaction time for preparing pure $\mathrm{LiNiVO}_{4}$. After low-temperature calcination, the microstructure of $\mathrm{LiNiVO}_{4}$ is uniform; however, it becomes non-uniform when the specimens 


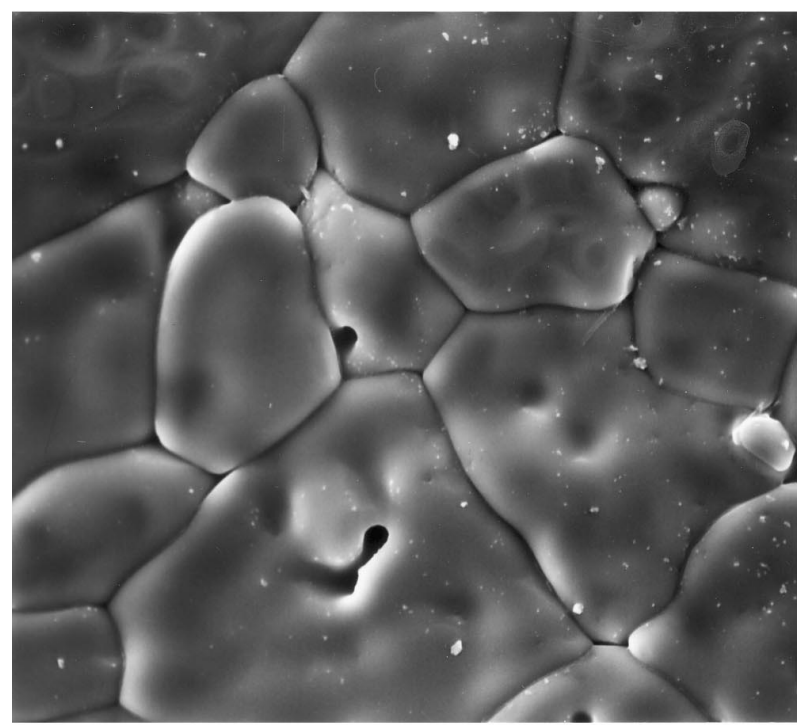

(a)
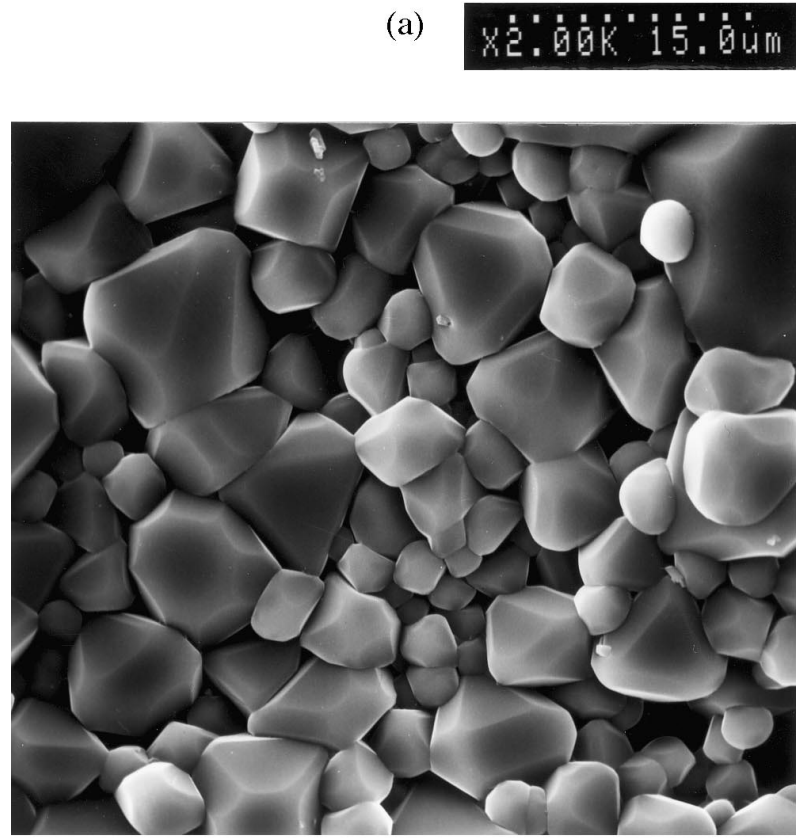

(b)

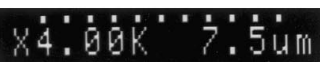

Fig. 8. Scanning electron micrographs of $\mathrm{LiNiVO}_{4}$ calcined at $800^{\circ} \mathrm{C}$ for $6 \mathrm{~h}$; (a) and (b) are the dark region and the matrix region shown in Fig. 7(d), respectively. are calcined at high temperatures for a prolonged period of time. The formation of the non-uniform microstructure is attributed to the regional compositional inhomogeneity which results in liquid-phase sintering and thereby causes exaggerated grain-growth of $\mathrm{LiNiVO}_{4}$ grains.

\section{Acknowledgements}

The authors gratefully acknowledge the financial assistance by the National Science Council, Taiwan, under Grant NSC 86-2214-E002-022.

\section{References}

[1] D.H. Doughty, Materials issues in lithium ion rechargeable battery technology, Sample J. 32 (1996) 75-81.

[2] A. Manthiram, Electrode materials for rechargeable lithium batteries, JOM 49 (1997) 43-46.

[3] R. Koksbang, J. Barker, H. Shi, M.Y. Saidi, Cathode materials for lithium rocking chair batteries, Solid State Ionics 84 (1996) $1-21$.

[4] G.T.K. Fey, W. Li, J.R. Dahn, $\mathrm{LiNiVO}_{4}$ : a 4.8 volt electrode material for lithium cells, J. Electrochem. Soc. 141 (1994) 22792282.

[5] G.T.K. Fey, New high voltage cathode materials for rechargeable lithium batteries, Active and Passive Elec. Comp. 18 (1995) $11-21$.

[6] J.C. Bernier, P. Poix, A. Michel, Spinel-type mixed vanadates, C. R. Hebd. Seances Acad. Sci. 253 (1961) 1578.

[7] Y. Ito, Phase relations of the lithium vanadate-nickel oxide $\left(\mathrm{LiVO}_{3}-\mathrm{NiO}\right)$ system and some properties of lithium nickel vanadate $\left(\mathrm{LiNiVO}_{4}\right)$, Nippon Kagaku Kaishi 11 (1979) 14831488

[8] G.T.K. Fey, W.B. Perng, A new preparation method for a novel high voltage cathode material: $\mathrm{LiNiVO}_{4}$, Mater. Chem. Phys. 47 (1997) 279-282.

[9] C.H. Lu, W.H. Hwang, Formation mechanism and relaxor ferroelectric properties of lead lithium iron tungstate ceramics, J. Mater. Res. 10 (1995) 2755-2763.

[10] C.H. Lu, Perovskite phase formation and microstructural evolution of lead magnesium tungstate-lead titanate ceramics, J. Mater. Sci. 31 (1996) 699-705.

[11] Powder diffraction file, card no. 38-1395, Joint Committee on Powder Diffraction Standards, Swarthmore, PA. 